\title{
EXPERIMENTALWORKS
}

\section{LIPOXYGENASE ACTIVITY IN ONTOGENESIS OF FERNS Salvinia natans AND Polystichum aculeatum}

\author{
L. M. BABENKO ${ }^{1}$, T. D. SKATERNA ${ }^{2}$ I. V. KOSAKIVSKA ${ }^{1}$ \\ ${ }^{1}$ M.G. Kholodny Institute of Botany, National Academy of Sciences of Ukraine, Kyiv; \\ ${ }^{2}$ Palladin Institute of Biochemistry, National Academy of Sciences of Ukraine, Kyiv; \\ e-mail: lilia.babenko@gmail.com
}

We analyzed the peculiarities of lipoxygenase (LOX) localization and activity in organs of two higher vascular cryptogams at the different phenological phases of development. For the first time it was showed that floating fronds of the annual water fern Salvinia natans (L.) contained 13-LOX with $\mathrm{pH}_{\text {opt }}$ value of 8.0, when submerged ones - 13-LOX $\left(\mathrm{pH}_{\text {opt }}\right.$ 8.0) at the initial phenological phases of development and 9-LOX $\left(\mathrm{pH}_{\text {opt }} 5.5\right)$ at the subsequent phases. In sporocarps 9-LOX $\left(\mathrm{pH}_{\text {opt }}\right.$ 5.5) was identified. At the same time in fronds of the perennial land fern Polystichum aculeatum (L.) Roth. we identified 13-LOX with $\mathrm{pH}_{\text {opt }}$ value of 7.74, and in the rhizome - 9-LOX ( $\mathrm{pH}_{\text {opt }}$ 7.54). The localization pattern and change of LOXs isoform activity in ferns organs in various phenological phases of development allow us to suggest that enzyme may be involved in the regulation of growth processes that ensure adaptation to environmental conditions.

Ke y word s: Salvinia natans (L.) All., Polystichum aculeatum (L.) Roth., lipoxigenases.

I ntensification of membrane lipids oxidation is a universal signaling mechanism that triggers the development of cell adaptation programs, and its initiation involves lipoxygenases. Lipoxygenases molecules (linoleate:oxygen oxydoreductase, EC 1.13.11.12, LOXs) contain non-gem iron [1-3] and catalyze stereo-specific peroxidation of polyunsaturated fatty acids (PUFA) that have at least one 1Z,4Z-pentadiene link [4]. Formation of hydroperoxides of trans- and cis-conjugated dienes is a key reaction in the lipoxygenase cascade that initiates seven enzyme branches [5], whose final products are biologically active metabolites - oxylipins $[5,6]$. These compounds are involved in the regulation of growth, development as well as formation of responses to environment signals and provide certain communication between living organism kingdoms [2, 3 7-10]. Search for specific DNA sequences in the data base GenBank, Refseq, Uniprot, Ensembl made it possible to establish the presence of LOX in ciano- and proteobacteria, the simplest unicellu- lar red and green sea algae, amoeba, fungi, mosses, angiosperms and animals [1,3]. Although a biological role of LOX in lower plants remains unclear, the occurrence of LOX sequence in their DNA suggests that the genus of these enzymes is evolutionary ancient and emerged after the emergence of oxygen on the Earth. LOX are thought to arise first in cianobacteria - the oldest life form [11]. In lower organisms LOX occur as hybrid enzymes in which the lipoxygenase domain may be associated with another catalytic domain, in particular, a peroxidase one. A biological role of hybrid enzymes is not fully understood but it has been shown that they are involved in biosynthesis of signaling molecules of lipid nature [12]. Algae and mosses contain significant quantities of $\mathrm{C}_{20}$-PUFAs (arachidonic and eicosapentaenoic) and $\mathrm{C}_{18}$-PUFAs ( $\alpha$-linolenic and linolenic) that are characteristic of animals, and which are typical lipoxygenase substrates in flower plants [13]. Physcomitrella patens were found to have LOX with $\mathrm{pH}_{\mathrm{opt}}$ of 7.0 and $\mathrm{pH}_{\mathrm{opt}}$ of 5.0 that produced (12S)-hy-

(C) 2017 Babenko L. M. et al. This is an open-access article distributed under the terms of the Creative Commons Attribution License, which permits unrestricted use, distribution, and reproduction in any medium, provided the original author and source are credited. 
droperoxide with arachidonic and eicosapentaenoic acids and (13S)- hydroperoxide with $\alpha$-linolenic acid. Thus, in mosses $\mathrm{C}_{20}$ - and $\mathrm{C}_{18}$-PUFAs may be oxidized with LOX and converted to biologically active oxylipins [14]. Due to the presence of $\mathrm{C}_{20}$-PUFAs the oxylipin spectrum in mosses was significantly larger compared to flower plants. However, jasmonic acid (JA) - one of the most active oxylipins in flower plants and mosses, is not synthesized [13].

According to the number of species, Polypodiophyta - the most numerous after angiosperms group of vascular plants, occupy the first place among the modern higher spore-bearing plants [15]. Occurrence of $\mathrm{C}_{20}$ - and $\mathrm{C}_{18}$-PUFAs in Polypodiophyta suggests that they contain lipoxygenases [16]. Information on LOX and products of their metabolic pathways in Polypodiophyta is limited [17-20]. So, Pteris vittata was shown to respond to Spodoptera littoralis infection in two ways similar to many flower plants: $\mathrm{H}_{2} \mathrm{O}_{2}$ synthesis and terpenoids emission [18]. However, the problem of oxylipins involvement in the growth and development regulation in higher vascular cryptogams is poorly understood and requires additional study. Thus, the aim of our study was to identify lipoxygenases in sporophytes of land fern Polystichum aculeatum (L.) Roth. and water fern Salvinia natans (L.) All., find the enzyme localization, reveal a possible functional role of LOX isoforms, localized in different plant organs, in the various phenological phases of development under different existence conditions.

\section{Materials and Methods}

Salvinia natans (L.) Roth. belongs to annual hydrophytes with a summer-green phenorythm type, occurs at the boundary between water and air [15, 20, 21]. We studied separated submerged (underwater) and floating (above-water) fronds and sporocarps of $S$. natans that grew under natural conditions in artificial water basins of Kyiv city. The analyzed phenological phases of sporophyte development were as follows: intensive growth, steady growth, formation of sporocarps and mature sporocarps.

Polystichum aculeatum (L.) Roth. - perennial land plant with an ever-green phenorythm type. After winter its fronds die out and emerge again in the middle of spring [22]. We studied plants that grew on the exposure plots of spore-bearing plants of academic O. V. Fomin Botanical Gardens, Kyiv National University. Fronds and rhizomes were separated from plant samples. The following phases of sporo- phyte phenological development were singled out: intensive growth, sorus formation, spore formation and phases of summer, autumn and winter vegetation. Monthly average air temperature during the period of sampling was: May $19^{\circ} \mathrm{C}$, June $21^{\circ} \mathrm{C}$, July 25 ${ }^{\circ} \mathrm{C}$, August $26^{\circ} \mathrm{C}$, September $16{ }^{\circ} \mathrm{C}$, October $2{ }^{\circ} \mathrm{C}$, February $-7^{\circ} \mathrm{C}$. Monthly average water temperature was: June $19^{\circ} \mathrm{C}$; July $22^{\circ} \mathrm{C}$, August $20^{\circ} \mathrm{C}$, September $11{ }^{\circ} \mathrm{C}$. Illumination of water basin surface at noon was $200-220 \mu \mathrm{M} / \mathrm{m}^{2} \cdot \mathrm{sec}^{-1}$ Illumination of the low stratum under the tree canopy at noon was 30-40 $\mu \mathrm{M} / \mathrm{m}^{2} \cdot \mathrm{sec}^{-1}$. Natural soils on the cryptogamic plants exposition site of the O. V. Fomin Botanical Gardens were represented by ashed, very loamy chernozem on forest loam soil having the following characteristics of the arable layer: $\mathrm{pH}_{\mathrm{KCl}}-5.7$, total humus content $-4.1 \%$, movable phosphorus and potassium compounds (according to Chirikov) - $138 \mathrm{mg} / \mathrm{kg}$ and $90 \mathrm{mg} / \mathrm{kg}$ of soil, respectively. Water chemical composition in the studied basin: acidity $-0.88 \mathrm{mg}$ equiv/1, alkalinity $-7.55 \mathrm{mg}$-equiv/1, total hardness $2.78 \mathrm{mg}$-equiv/l, dissolved oxygen $-5.15 \mathrm{mg} / \mathrm{l}$, $\mathrm{HCO}_{3}-3.01 \mathrm{mg}$-equiv $/ \mathrm{dm}^{3}, \mathrm{Cl}-0.79 \mathrm{mg}$-equiv $/ \mathrm{dm}^{3}$, $\mathrm{SO}_{4}^{2-}-1.03 \mathrm{mg}$-equiv/dm ${ }^{3}, \mathrm{Mg}^{2+}-1.201 \mathrm{mg}$-equiv/ $\mathrm{dm}^{3}, \mathrm{Na}^{+}$and $\mathrm{K}^{+}-1.1 \mathrm{mg}$-equiv/dm ${ }^{3}$. Soil and water composition remained the same for the whole experiment period. For each repeated biological trial 40 plants were selected.

To isolate LOX preparations, plant samples were homogenized in cooled to $4{ }^{\circ} \mathrm{C} 0.1 \mathrm{M}$ phosphate buffer ( $\mathrm{pH}$ 6.3), which contained $2 \mathrm{mM}$ phenylmethylsulfonyl fluoride, $0.04 \%$ sodium metabisulfite. Homogenate was centrifuged (K-24, Germany) at $4000 \mathrm{~g}$ for $30 \mathrm{~min}$ at $4{ }^{\circ} \mathrm{C}$. Obtained supernatant was used to determine LOX activity. To construct curves of $\mathrm{pH}$-dependence of lipoxygenase oxidation standard rates of linoleic acid, $0.1 \mathrm{M}$ sodium-acetate ( $\mathrm{pH}$ 4.0-5.5), 0.1 M sodium-phosphate ( $\mathrm{pH}$ 6.0-8.0) and borate $0.1 \mathrm{M}(\mathrm{pH}$ 8.0-9.5) buffer solutions were used. Linoleic acid concentrations in $2.5 \mathrm{ml}$ reaction mixture were $40-100 \mu \mathrm{M}$, with or without $50 \mu \mathrm{M}$ of lubrole. The 9- and 13-LOX activities were determined spectrophotometrically at $234 \mathrm{~nm}$ using linoleic acid as substrate at $\mathrm{pH} 4.5-9.5$ in the presence or absence of $50 \mu \mathrm{M}$ lubrole, respectively [23].

LOX activity was measured using the spectrophotometer Specord M-40 (Carl Zeiss Jen, Germany). Reaction was initiated by adding 50$100 \mu \mathrm{l}$ of enzyme solution (protein concentration of $0.5-1.0 \mathrm{mg} / \mathrm{ml}$ ) and at the constant temperature of $25 \pm 0.1{ }^{\circ} \mathrm{C}$. Reaction was observed considering 
an increase in reaction mixture optical density at $\lambda=235 \mathrm{~nm}$ that corresponds to maximum absorption of conjugate diene chromophore in molecules of linoleic acid hydroperoxide whose molar extinction coefficient is $23000 \mathrm{M}^{-1} \cdot \mathrm{cm}^{-1}$ [24]. Protein content was measured according to the method [25]. Biological tests were repeated twice and analytical assessment thrice. When constructing kinetic dependence curves we used average values of $\mathrm{V}_{\mathrm{st}}$, which were determined in three measurements (difference between values was not more than 5\%). Findings were statistically processed using Student's $t$-test, difference at $P \leq 0.05$ was regarded as statistically reliable. The bars in the graphs represent the standard deviation

\section{Results and Discussion}

A mature sporophyte of $S$. natans is characterized by a clonal structure, it is produced during formation of new modules that develop radially near the central (the oldest) part of the plant. The clone structure complexity is determined by its age. The clone growth is similar to that of lateral branches in vascular plants. We observed clone growing in JuneAugust at water $19-20^{\circ} \mathrm{C}$. Clone disintegration into individual modules coincided with the emergence and development of sporocarps (the third decade of August - beginning of September) and water temperature decrease. Biometric studies results concerning an intact plant (clone) and individual segments of floating and submerged fronds of the main adult plant in the various phenological phases of $S$. natans sporophyte development are given in Table 1. An individual submerged frond mass and length were established to exceed those of a floating frond. It was typical of floating fronds in general to show an insignificant increase in biometric indices. At the same time, mass and length of sporophyte floating part increased from 22 to $40 \mathrm{mg}$ and 45 to $62 \mathrm{~mm}$, respectively due to newly produced fronds and stem elongation (Table 1). At the stage of stable growth, due to an intensive formation of multicellular filamentary hairs, the mass of an individual submerged frond increased two times while the length remained almost unchanged. At the stage of reproductive development, the sporophyte mass grew due to the sporocarps formation (Table 1).

Thus, the biometric analysis indicates that changes in mass and length of $S$. natans sporophytes occurred mostly due to newly formed organs (modules), while linear dimensions of individual formed fronds in the main adult plant remained almost unchanged.

As a result of studies, we have first identified activity of 13- and 9-lipoxygenases in organs of the water fern $S$. natans in various phenological phases of development. Floating fronds were shown to contain 13-LOX with $\mathrm{pH}$ opt value of 8.0, while submerged fronds in the first two phenological phases of development had 13-LOX $\left(\mathrm{pH}_{\mathrm{opt}} 8.0\right)$, and in the third phase - 9-LOX ( $\mathrm{pH}_{\mathrm{opt}}$ 5.5). Sporocarps were found to have 9-LOX with $\mathrm{pH}_{\mathrm{opt}}$ value of 5.5 (Fig. 1).

At the sporophyte intensive growth phase the 13-LOX activity in floating fronds was $2.63 \mu$ mole $\mathrm{LAH} / \mathrm{min} \cdot \mu \mathrm{g}$ protein (LAH-linoleic acid hydroperoxide). During another phase the activity gradually decreased, and then it increased again, reaching its maximum during sporocarp formation that coincided in time with degradation of thylakoid membranes and formation of a significant number of plastoglobules in chloroplast stromata [26]. In submerged fronds 13-LOX activity was identified only in the phase of sporophyte intensive growth. Activi-

Table 1. Biometric characteristics of fronds at the various phenological stages of S. natans sporophyte development

\begin{tabular}{|c|c|c|c|c|c|c|c|c|}
\hline \multirow{3}{*}{$\begin{array}{l}\text { Phenolo- } \\
\text { gical stages }\end{array}$} & \multicolumn{2}{|c|}{ Whole plant } & \multicolumn{4}{|c|}{ Floating fronds } & \multicolumn{2}{|c|}{ Submerged fronds } \\
\hline & \multirow[b]{2}{*}{ Weight, g } & \multirow[b]{2}{*}{$\begin{array}{l}\text { Length, } \\
\text { cm }\end{array}$} & \multicolumn{2}{|c|}{ One frond } & \multicolumn{2}{|c|}{ Fronds all plants } & \multirow[b]{2}{*}{ Weight, g } & \multirow{2}{*}{$\begin{array}{l}\text { Length, } \\
\mathrm{cm}\end{array}$} \\
\hline & & & Weight, g & $\begin{array}{l}\text { Length, } \\
\text { cm }\end{array}$ & Weight, g & $\begin{array}{l}\text { Length, } \\
\text { cm }\end{array}$ & & \\
\hline & $0.35 \pm 0.02$ & $4.5 \pm 0.2$ & $0.01 \pm 0.001$ & $0.80 \pm 0.04$ & $0.22 \pm 0.01$ & $4.50 \pm 0.22$ & $0.10 \pm 0.005$ & $4.20 \pm 0.21$ \\
\hline $\begin{array}{l}\text { Steady } \\
\text { growth }\end{array}$ & $0.47 \pm 0.02$ & $5.30 \pm 0.27$ & $0.01 \pm 0.001$ & $0.90 \pm 0.05$ & $0.28 \pm 0.01$ & $5.30 \pm 0.27$ & $0.16+0.008$ & $4.30 \pm 0.25$ \\
\hline $\begin{array}{l}\text { Sporocarps } \\
\text { formation }\end{array}$ & $0.79 \pm 0.04$ & $6.20 \pm 0.31$ & $0.01 \pm 0.001$ & $1.10 \pm 0.06$ & $0.40 \pm 0.02$ & $6.20 \pm 0.31$ & $0.16 \pm 0.007$ & $4.10 \pm 0.21$ \\
\hline
\end{tabular}




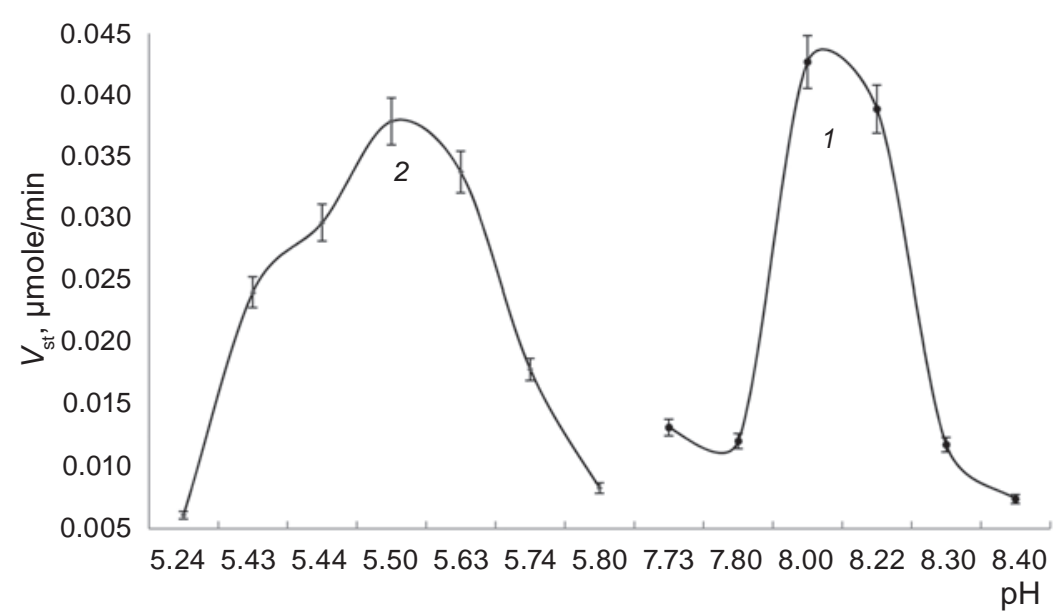

Fig. 1. Dependence of reaction stationary rate $\left(V_{s}\right)$ of linoleic acid oxidation on incubation environment $p H$ in $S$. natans floating (1) and submerged fronds and sporocarps (2)

ty of 9-LOX was revealed in submerged fronds and sporocarps. During sporocarp formation submerged fronds were found to have a peak activity of 9-LOX. At the beginning of sporocarps formation LOX activity in these organs reached $1.32 \mu$ mole LAH/ $\min \cdot \mu \mathrm{g}$ protein, while in mature sporocarps after a complete dying out of the sporophyte vegetative part - $4.26 \mu$ mole LAH/min $\mu$ g protein (Fig. 2).

The localization pattern and change of lipoxygenase isoform activity in fern organs in various phenological phases of development allow the enzyme to be considered one of the endogenous factors that is involved in the regulation of important lipids metabolic pathways of growth processes that ensure the success of adaptation to environmental conditions.

Results of biometric studies on plant individual fronds and rhizome at the various phenological stages $P$. aculeatum sporophyte are presented in Table 2. Fronds mass and their elongation were found to increase until the summer vegetation phase. After spores emergence and frond growth cessation their mass gradually decreased, while frond length after unfolding remained practically unchanged (Table 2). A four-fold increase of fern rhizome mass was observed in the phase of sorus formation, which did not change any more and was in the range of 190$193 \mathrm{~g}$ (Table 2). In contrast to fronds elongation, changes in rhizome length were less intensive and it reached its maximum of $31.2 \mathrm{~cm}$ in the summer vegetation phase. Growth slowdown and transition to the autumn and winter vegetation resulted in some decrease of the rhizome length, which was 29.3 and $29.1 \mathrm{~cm}$, respectively, that, as we think, was due to die-out of upper tips of lateral secondary roots as a result of environment temperature drops. So, growth intensity in sporophyte overground and underground organs during ontogenesis was different. The frond length varied from 13.2 to $63.1 \mathrm{~cm}$, while rhizome length - from 20.8 to $31.2 \mathrm{~cm}$. Frond and rhizome length and mass maximum were observed in the summer vegetation phase. At the stage of autumn and winter vegetation, when fern development slowed down, there took place a tendency of frond and rhizome mass reduction.

We also for the first time identified lipoxygenase activity in sporophyte organs of the land fern P. aculeatum. Activity of $13-\mathrm{LOX}$ with $\mathrm{pH}_{\mathrm{opt}}$ value of 7.74 was detected in fronds and 9-LOX activity with

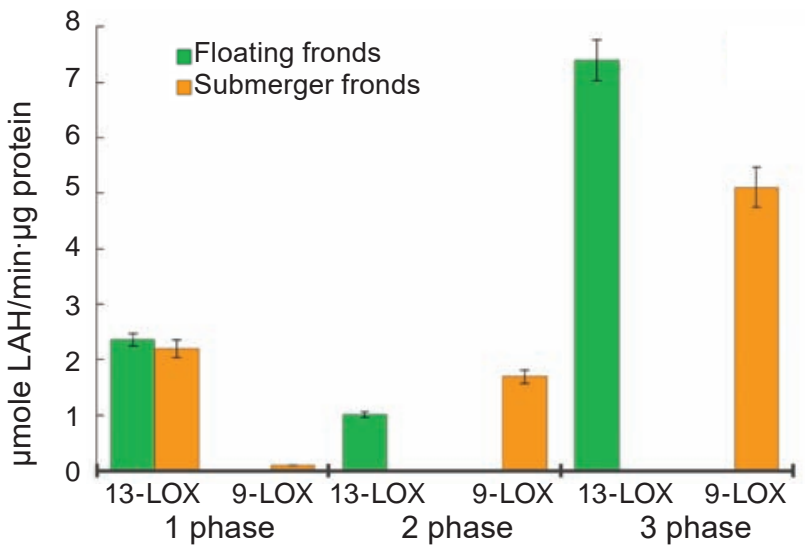

Fig. 2. Distribution of LOX activity in S. natans organs in different phenological phases of sporophyte development: 1 - growth intensity; 2 - steady growth; 3 - sporocarps formation. LAH - linoleic acid hydroperoxide 
Table 2. Biometric characteristics of fronds and rhizome at various phenological stages of Polystichum aculeatum (L.) Roth. sporophyte development

\begin{tabular}{l|r|c|c|c}
\hline \multirow{2}{*}{ Phenological stages } & \multicolumn{2}{|c|}{ Fronds } & \multicolumn{2}{c}{ Rhizome } \\
\cline { 2 - 5 } & Weight, g & Length, cm & Weight, g & Length, cm \\
\hline Growth intensity & $1.9 \pm 0.1$ & $13.2 \pm 0.7$ & $44.5 \pm 2.3$ & $20.8 \pm 1.1$ \\
Sorus formation & $4.6 \pm 0.3$ & $47.6 \pm 2.4$ & $190.2 \pm 9.5$ & $29.5 \pm 1.5$ \\
Sporiferous & $7.8 \pm 0.4$ & $50.4 \pm 2.5$ & $191.0 \pm 9.6$ & $29.1 \pm 1.3$ \\
Summer vegetation & $10.6 \pm 0.3$ & $63.1 \pm 4.2$ & $193.4 \pm 8.7$ & $31.2 \pm 2.1$ \\
Autumn vegetation & $9.3 \pm 0.1$ & $61.4 \pm 3.1$ & $190.1 \pm 8.5$ & $29.3 \pm 2.4$ \\
Winter vegetation & $6.3 \pm 0.3$ & $61.4 \pm 3.9$ & $174.1 \pm 9.1$ & $29.1 \pm 1.4$ \\
\hline
\end{tabular}

pH opt value of 7.54 in the rhizome (Fig. 3). Our previous studies demonstrated that vegetative shoots of Equisetum arvense L. that belongs to higher vascular cryptogams, had a similar pattern of LOX activity distribution [27]. Our analysis indicated that during spring vegetation LOX activity in fronds increased, reaching its maximum in the sporiferous phase that, as we think, is due to active metabolic processes during spore maturation (Fig. 4). Oxylipins - metabolites of the allene oxide synthase branch of LOXpathway, particularly JA and its methyl alcohol, are known to promote fruit maturation [3, 10, 28, 29].

Following the sporiferous phase the 13-LOX activity decreased almost two times and reached its minimum values in the winter vegetation phase. Maximum 9-LOX activity was observed at the winter vegetation, whereas minimum values - in the sporiferous phase. During the summer vegetation and up to the autumn beginning the 9-LOX activity was almost unchanged and that seems to be associa- ted with the transition of the metabolic activity center from the fern rhizome to over-ground part (Fig. 4).

Our previous studies of the vascular cryptogam E. arvense showed that $13-\mathrm{LOX}$ activity with $\mathrm{pH}_{\mathrm{opt}}$ value of 7.2 was in strobile, internodes and leaves of generative shoots and that of 9-LOX with $\mathrm{pH}_{\mathrm{opt}}$ value of 4.2 in the rhizome and strobile. In vegetative shoots, on the contrary, 13-LOX activity was detected exclusively in shoots while that of 9-LOX - only in the rhizome [27]. Activity of 9-LOX is typical of the higher plant root system where the enzyme is localized in cell cytosol. In higher plants 9-hydroperoxides of PUFAs are predecessors of compounds that stimulate the synthesis of ketoles, which induce flowering, provide coloration of flowers, defense and programmed cell of leaves affected by pathogens and regulate tubirization [3]. Activity of 9- and 13LOX varies depending on a phenological phase of E. arvense sporophyte development that coincides

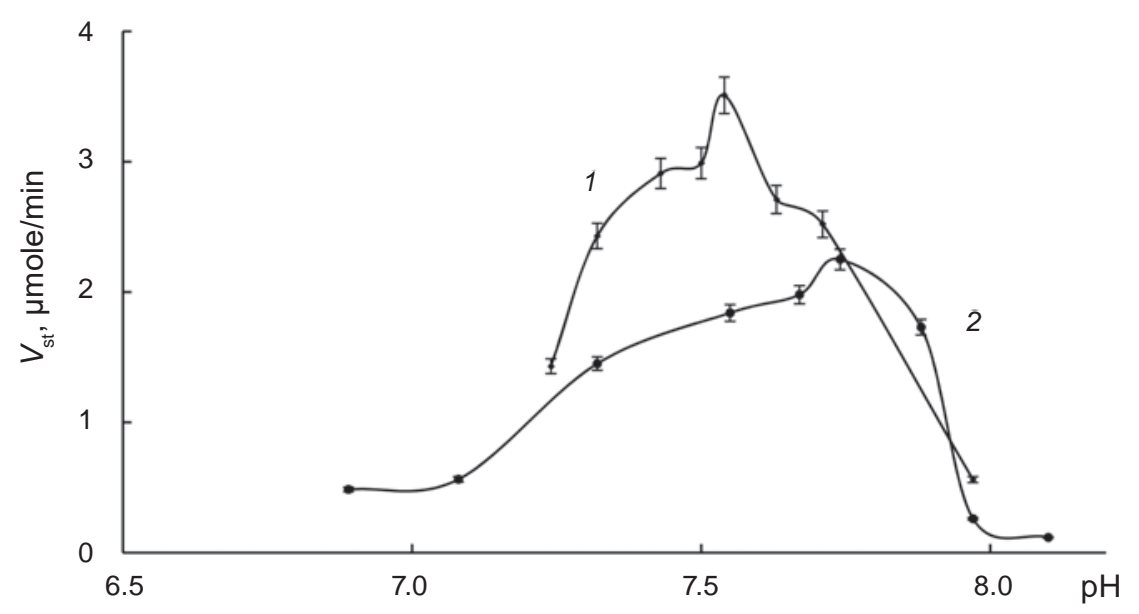

Fig. 3. Dependence of the stationary rate $\left(V_{s}\right)$ of oxidation reaction of linoleic acid on $\mathrm{pH}$ of incubation environment in P. aculeatum rhizome (1) and fronds (2) 


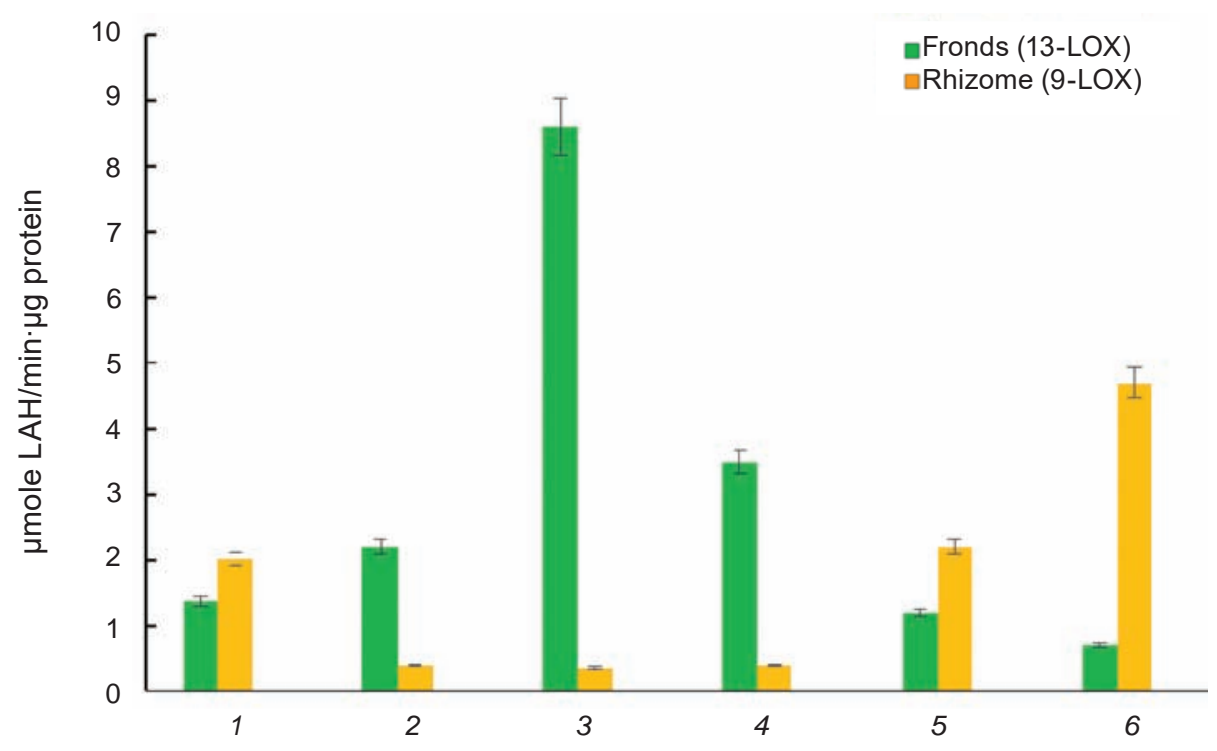

Fig. 4. Lipoxygenase activity in sporophyte organs of P. aculeatum in different phenological phases of development: 1 - intensive growth beginning; 2 - sorus formation; 3 - sporiferous phase; 4 - summer vegetation; 5 - autumn vegetation; 6 - winter vegetation; LAH - linoleic acid hydroperoxide

with data obtained on $S$. natans and $P$. aculeatum. E. arvense 9-LOX activity in the rhizome following spores emergence (at the beginning of generative shoot dying out) considerably increased, whereas that of 13-LOX, on the contrary, decreased. At the end of $E$. arvense assimilative shoots vegetation a high 9-LOX activity was in rhizomes that corresponded to the formation of starch-containing bulbs [27]. In S. natans a considerable increase in 9-LOX activity occurred at the final stage of sporocarp formation, when a vegetative part of sporophyte was actually dead. A certain increase in 9-LOX activity also occurs in submerged fronds at the beginning of sporocarp formation. In P. aculeatum 9-LOX activity maximum took place in the winter phase of vegetation that appears to be related with the transition of the metabolic activity center from the underground part to fern rhizome. So, our data shows that there is some relation between changes in activity and localization of this enzyme and generative organs formation and ripening. However, it should be noted that physiological functions of 9-LOX metabolites of PSFAs in pteridophytes have not yet been finally identified.

In pteridophytes there were studied mainly 13LOX metabolites of $\mathrm{C}_{18}$-PUFAs - volatile organic compounds (VOC) $[18,19]$.

So, as a result of our studies the two lipoxigenase isoforms - 13-LOX and 9-LOX were for the first time identified in organs of the water fern
S. natans and land fern P. aculeatum, and their catalytic activity was determined. The enzyme distribution pattern in $S$. natans floating and submerged fronds and sporocarps and in $P$. aculeatum fronds and rhizome in different phenological phases of development was established. Features discovered in the LOX-activity distribution in $S$. natans and $P$. aculeatum organs during transition from one to another phenological phase of development, indicate indirectly a signaling function and give grounds to consider lipoxygenase one of endogenous regulation factors involved in vegetation and generation under different existence conditions.

\section{ЛІПОКСИГЕНАЗНА АКТИВНІСТЬ В ОНТОГЕНЕЗІ ПАПОРОТЕЙ Salvinia natans TA Polystichum aculeatum}

\author{
Л. М. Бабенко ${ }^{1}$, Т. Д. Скатерна ${ }^{2}$, \\ I. В. Косаківська ${ }^{1}$ \\ ${ }^{1}$ Інститут ботаніки ім. М. Г. Холодного \\ НАН України, Київ; \\ ${ }^{2}$ Інститут біохімії ім. О. В. Палладіна \\ НАН України, Київ; \\ e-mail: lilia.babenko@gmail.com
}

Проаналізовано особливості локалізації та активності ліпоксигеназ (LOX) в органах двох вищих судинних спорових рослин на різних фенологічних фазах розвитку. Уперше встановлено, що у плаваючих ваях однорічної папороті- 
гідрофіта S. natans (L.) міститься 13-LOX $\left(\mathrm{pH}_{\text {опт }} 8,0\right)$, у занурених - $13-\mathrm{LOX}\left(\mathrm{pH}_{\text {опт }} 8,0\right)$ на початкових фенологічних фазах розвитку, а на наступних фазах 9-LOX $\left(\mathrm{pH}_{\text {опт }} 5,5\right)$. У спорокарпіях ідентифіковано 9-LOX ( $\mathrm{pH}_{\text {опт }}$ 5,5). У ваях багаторічної суходольної папороті $P$. aculeatum (L.) Roth. ідентифікована 13-LOX $\left(\mathrm{pH}_{\text {опт }} 7,74\right)$, a у кореневищі - 9-LOX ( $\mathrm{pH}_{\text {опт }}$ 7,54). Характер локалізації і зміна активності ізоформ LOX в органах папоротей на різних фенологічних фазах розвитку дозволяють припустити, що ензим може бути залучений до регуляції ліпідного метаболізму ростових процесів, що забезпечують адаптацію рослин до навколишнього середовища.

К л ю ч о в і с л о в а: Salvinia natans (L.) All., Polystichum aculeatum (L.) Roth., ліпоксигенази.

\section{ЛИПОКСИГЕНАЗНАЯ АКТИВНОСТЬ В ОНТОГЕНЕЗЕ ПАПОРОТНИКОВ Salvinia natans И Polystichum aculeatum}

\author{
Л. М. Бабенко , Т. Д. Скатерная ${ }^{2}$, \\ И. В. Косаковская \\ ${ }^{1}$ Институт ботаники им. Н. Г. Холодного \\ НАН Украины, Киев; \\ ${ }^{2}$ Институт биохимии им. А. В. Палладина \\ НАН Украины, Киев; \\ e-mail: lilia.babenko@gmail.com
}

Проанализированы особенности локализации и активности липоксигеназ (LOX) в органах двух высших сосудистых споровых растений на разных фенологических фазах развития. Впервые показано, что на начальных фенологических фазах развития плавающие ваи однолетнего водного папоротника S. natans (L.) содержат 13-LOX ( $\left.\mathrm{pH}_{\text {opt }} 8,0\right)$, погруженные - 13-LOX $\left(\mathrm{pH}_{\text {опт }} 8,0\right)$ на начальных фенологических стадиях развития, а на последующих фазах 9-LOX $\left(\mathrm{pH}_{\text {опт }} 5,5\right)$. В спорокарпиях идентифицирована 9-LOX ( $\left.\mathrm{pH}_{\text {опт }} 5,5\right)$. В то же время, в ваях многолетнего наземного папоротника P. aculeatum (L.) Roth. идентифицировали 13-LOX ( $\mathrm{pH}_{\text {опт }}$ 7,74), a в корневище - 9-LOX ( $\mathrm{pH}_{\text {опт }}$ 7,54). Характер локализации и изменения активности изоформ LOX в органах папоротников на различных фенологических фазах развития позволяют предположить, что энзим может быть вовлечен в регуляцию липидного метаболизма ростовых процессов, которые обеспечивают адаптацию растений к условиям окружающей среды.

К л юче вы е с ло в а: Salvinia natans (L.) All., Polystichum aculeatum (L.) Roth., липоксигеназы.

\section{References}

1. Ivanov I, Heydeck D, Hofheinz K, Roffeis J, O'Donnell VB, Kuhn H, Walther M. Molecular enzymology of lipoxygenases. Arch Biochem Biophys. 2010; 503(2): 161-174.

2. Borrego EJ, Kolomiets MV. Lipid-mediated signaling between fungi and plants. In Biocommunication of Fungi; Springer: New York, NY, USA, 2012: 249-260.

3. Babenko LM, Shcherbatiuk MM, Skaterna TD, Kosakivska IV. Lipoxygenases and their metabolites in formation of plant stress tolerance. Ukr Biochem J. 2017; 89(1): 5-21.

4. Joo YC, Oh DK. Lipoxygenases: potential starting biocatalysts for the synthesis of signaling compounds. Biotechnol Adv. 2012; 30(6): 15241532.

5. Feussner I, Wasternack C. The lipoxygenase pathway. Annu Rev Plant Biol. 2002; 53: $275-$ 297.

6. Gao X, Stumpe M, Feussner I, Kolomiets M. A novel plastidial lipoxygenase of maize (Zea mays) ZmLOX6 encodes for a fatty acid hydroperoxide lyase and is uniquely regulated by phytohormones and pathogen infection. Planta. 2008; 227(2): 491-503.

7. Christensen SA, Kolomiets MV. The lipid language of plant-fungal interactions. Fungal Genet Biol. 2011; 48(1): 4-14.

8. Babenko L, Voytenko L, Skaterna T, Musatenko L. Lipoxygenase activity in Equisetum arvense L. ontogenesis. Fiziol Rast Genet. 2014; 46(1): 37-44. (In Ukrainian).

9. Savchenko TV, Zastrijnaja OM, Klimov VV. Oxylipins and plant abiotic stress resistance. Biochemistry (Mosc). 2014; 79(4): 362-375.

10. Wasternack C, Song S. Jasmonates: biosynthesis, metabolism, and signaling by proteins activating and repressing transcription. J Exp Bot. 2017; 68(6): 1303-1321.

11. Andreou A, Göbel C, Hamberg M, Feussner I. A bisallylic mini-lipoxygenase from cyanobacterium Cyanothece sp. that has an iron as 
cofactor. J Biol Chem. 2010; 285(19): 1417814186.

12. Koljak R, Boutaud O, Shieh BH, Samel N, Brash AR. Identification of a naturally occurring peroxidase-lipoxygenase fusion protein. Science. 1997; 277(5334): 1994-1996.

13. Ponce de León I, Hamberg M, Castresana C. Oxylipins in moss development and defense. Front Plant Sci. 2015; 6: 483.

14. Anterola A, Göbel C, Hornung E, Sellhorn G, Feussner I, Grimes H. Physcomitrella patens has lipoxygenases for both eicosanoid and octadecanoid pathways. Phytochemistry. 2009; 70(1): 40-52.

15. Babenko LM, Sheyko OA, Kosakivska IV, Vedenichova NP, Nehretskiy VA, Vasheka OV. Structural and functional characteristics of pteridophytes (Polypodiophyta). Bull Kharkiv Nat Agrar Univ. Ser. Biology. 2015; 1(34): 80103. (In Ukrainian).

16. Rozentsvet OA, Bogdanova ES, Murzaeva SV. Composition of lipids and fatty acids in the forming leaves of the fern Matteuccia sthruthiopteris in the presence of cadmium. Trans Karelian Res Centre RAS. 2011; 3: 97-104 (In Russian).

17. Boland W, Hopke J, Donath J, Nuske J, Bublitz F. Jasmonic acid and coronatine induce odor production in plants. Angew Chem Int Ed Engl. 1995; 34(15): 1600-1602.

18. Imbiscuso G, Trotta A, Maffei M, Bossi S. Herbivory induces a ROS burst and the release of volatile organic compounds in the fern Pteris vittata L. J Plant Interac. 2009;4(1): 15-22.

19. Radhika V, Kost C, Bonaventure G, David A, Boland W. Volatile emission in bracken fern is induced by jasmonates but not by Spodoptera littoralis or Strongylogaster multifasciata herbivory. PLoS One. 2012; 7(11): e48050.

20. Babenko LM, Skaterna TD, Kosakivska IV. Lipoxygenase activity in ontogenesis of water fern Salvinia natans (L.) ALL. Dop NAN Ukrainy. 2016; 8: 101-108. (In Ukrainian).
21. Nagalingum NS, Schneider H, Pryer KM. Comparative morphology of reproductive structures in heterosporous water ferns and a reevaluation of the sporocarps. Int $J$ Plant Sci. 2006; 167(4): 805-815.

22. Vasheka AV, Brayon OV. Classification of rhythms of seasonal development of ferns in regions with temperate climate. Bull Taras Shevchenko Nat Univ Kyiv. Series Introduct Conserv Plant Divers. 2000; 3: 24-28 (In Ukrainian).

23. Kopich VN, Kretynin SV, Kharchenko OV, Litvinovskaya RP, Chashina NM, Khripach VA. Effect of 24-epibrassinolide on lipoxygenase activity in maize seedlings under cold stress. Biopolym Cell. 2010; 26(3): 218-224.

24. Gibian MJ, Vandenberg P. Product yield in oxygenation of linoleate by soybean lipoxygenase: the value of the molar extinction coefficient in the spectrophotometric assay. Anal Biochem. 1987; 163(2): 343-349.

25. Bradford MM. A rapid and sensitive method for the quantitation of microgram quantities of protein utilizing the principle of protein-dye binding. Anal Biochem. 1976 May;72(1-2):248254.

26. Babenko LM, Shcherbatiuk MM, Polishchyk OV, Kosakivska IV. Structural-functional peculiarities of water fern Salvinia natans (L.) ALL. Studia Biologica. 2016; 10(2): 149-162. (In Ukrainian).

27. Babenko LM, Shcherbatiuk MM, Kosakivska IV. Lipoxygenase activity and rhizomes ultrastructure of vegetative and generative shoots Equisetum arvense L. Studia Biologica. 2015; 9(1): 53-162. (In Ukrainian).

28. Babenko LM, Kosakivska IV, Skaterna TD. Jasmonic acid: role in biotechnology and the regulation of plants biochemical processes. Biotechnol Acta. 2015; 8(2): 36-51.

29. Borrego EJ, Kolomiets MV. Synthesis and Functions of Jasmonates in Maize. Plants (Basel). 2016; 5(4). pii: E41.

Received 19.04.2017 